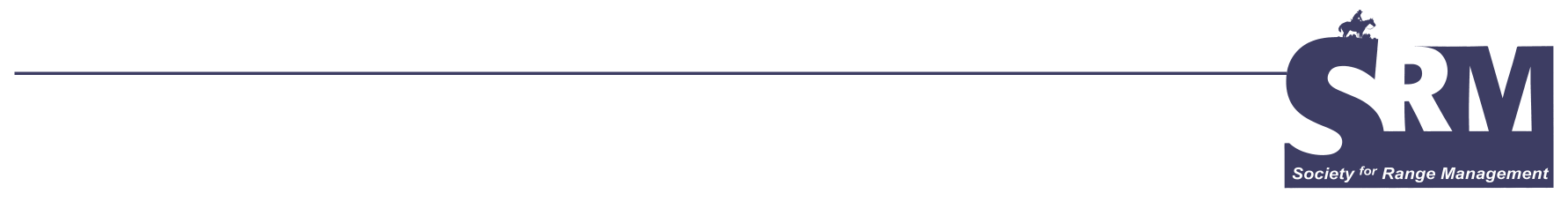

\title{
Barriers to Successful Drought Management: Why Do Some Ranchers Fail to Take Action?
}

\section{By Barry Dunn, Alexander Smart, and Roger Gates}

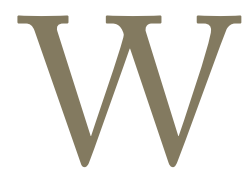

hy does drought impact ranchers and their operations differently? Are there factors affecting the severity of the impact of drought other than precipitation and temperature? The drought of 2002 in the northern Great Plains provided the opportunity to observe ranchers' responses to drought. In South Dakota, the authors observed a wide range of responses, from no modification of management to implementation of a deliberate and appropriate droughtresponse plan. Anticipating low rainfall and having the flexibility to handle it has been the common advice from rangeland-management professionals and ranchers that have successfully weathered previous droughts. Yet there are barriers that hinder ranchers from responding effectively to drought. Our objective is to suggest reasons that ranchers may be unresponsive to drought. Our hope is that a deeper understanding of ranchers' responses to drought will lead to improved response in the future. The beneficiaries of an improved response to drought will be rangeland resources, ranchers and their families, and society in general.

\section{Learning, Paradigms, and Mental Models}

Ranchers may not be aware of the historic weather patterns and the expectations of drought in the northern Great Plains (see article by Smart et $\mathrm{al}^{1}$ ). Prior to 2002, favorable spring growing conditions had occurred 7 years in a row in western South Dakota. Given this pattern, the frequency of occurrence of 8 consecutive years of above-normal or normal spring rainfall was very low. In fact, such a pattern only occurred 1 time out of 27 periods, or 4\%, between years with below-normal spring rainfall during the last 95 years. Ranchers and rangeland resource professionals should have been expecting a drought. Also, the occurrence of back-toback spring droughts was $33 \%$. Potential risk of reduced forage production was great. Knowing and understanding historic precipitation patterns is a critical first step to a well thought out and planned response.

Sensitivity to drought is influenced by experience. For example, ranchers who grew up during the 1960s in western South Dakota would have only experienced 6 spring droughts during the next 40 years (see article by Smart et $\mathrm{al}^{1}$ ). However, if they had grown up ranching in the 1920s, they would have experienced 10 spring droughts, 3 of them lasting for 2 or more years. A majority of ranchers operating in 2002 grew up during the 1950s and 1960s.

One's capacity to recall the impact of previous below-normal precipitation is difficult because we are heavily influenced by our most recent memories. For example, prior to the drought of 2002, at South Dakota State University's Cottonwood Range and Livestock Station in western South Dakota, the last dry spring had been in 1994. Forage yield from pastures on the Cottonwood Station averaged 1500 pounds/acre from 1997 to 2001. In 2002, the forage yield from these same pastures was reduced by $50 \%$. When ranchers and rangeland professionals observe forage production during good years, especially for extended periods, it is easy to forget conditions during bad years.

Senge's work "The fifth discipline: the art and practice of the learning organization," published in 1990, defines a mental model as a deeply held assumption, or generalization, that influences one's views and interactions with the world. Do ranchers view their grasslands or their cows as their basic ranch factory? What is their mental model of a ranch production system? Is it based on cattle or grass? The 

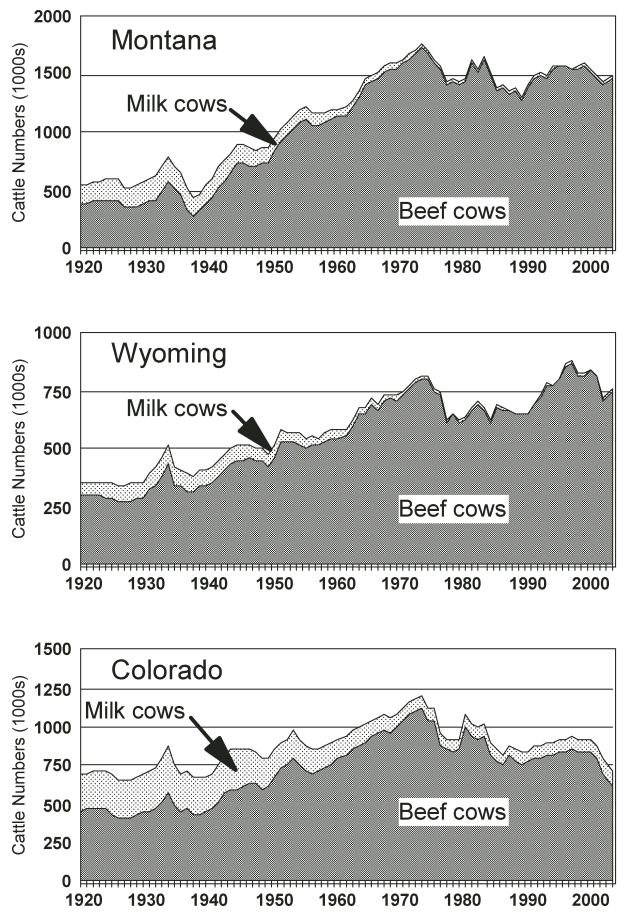
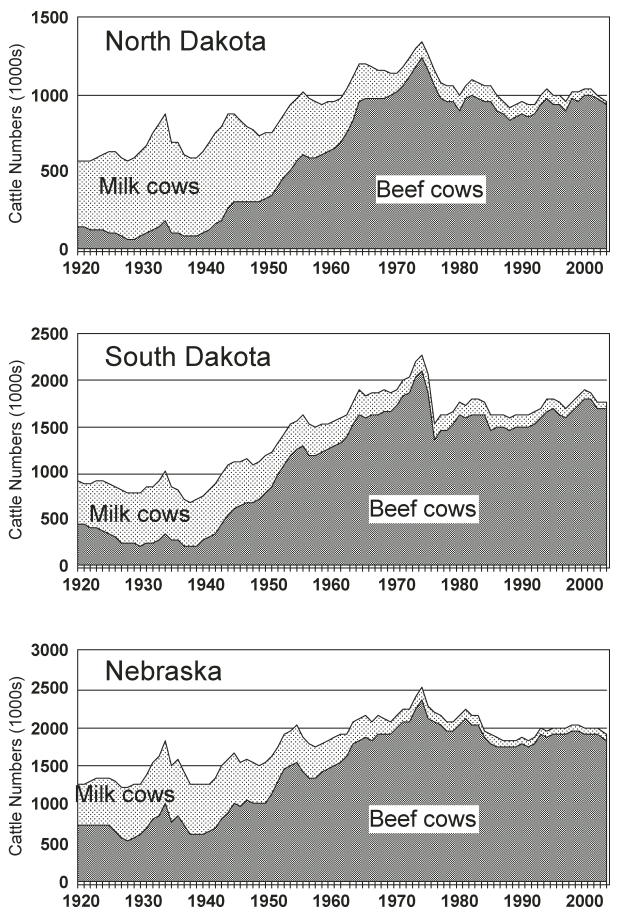

Figure 1. January 1 livestock inventories of beef and milk cows for states in the northern Great Plains from 1920 to $2004{ }^{11}$

6\% decline in cow numbers from January 2002 to January 2003 in South Dakota (Fig. 1), while forage production in many areas dropped $50 \%$, is evidence that ranchers view their cows, rather than their grasslands, as their factory. Understanding this mental model is critical in understanding rancher response to drought. From a rancher's perspective, investments in livestock genetics, market considerations, public policy, and an inherent positive attitude that negative short-term conditions will be buffered by longterm trends are strong incentives not to liquidate livestock. Evidence of this behavior is provided by the increasing cowinventory trend from the northern Great Plains states (Fig. 1). How tightly this belief system is held has powerful implications for the health of both the rangeland and financial resources of ranchers.

\section{Financial}

In eco-regions like the northern Great Plains that experience periodic droughts, minimizing risk exposure is a key to sustainable long-term ranching success. Conservative stocking rates or flexible stocking alternatives have long been recognized as key strategies. One problem is that flexibility provided by maintaining different age classes of livestock is not in widespread practice, as it once was. The once common practice of grazing yearling cattle to harvest excess forage in years when it is abundant has been replaced by maintenance of larger cow herds. Inventories for yearling cattle on grazing lands are not available, but beef-cow numbers from 1920 to
2004 in the Great Plains states (Fig. 1) has risen dramatically. Grazing acres in this region have stayed fundamentally the same, indicating that this shift in inventory from yearlings to cows has probably occurred. There are many potential reasons explaining the phenomenon. Cattle genetics have changed dramatically during this period of time, responding to market signals demanding fast-growing animals. So the potential supply of desirable yearling cattle for grazing is smaller than it once was. In addition, surveys published in 1982 by Dooley et $\mathrm{al}^{3}$ and in 2003 by Dunn et $\mathrm{al}^{4}$ demonstrate that, in South Dakota, average calving dates are now approximately 60 days earlier in the year. Earlier calving decreases available supplies of desirable yearling cattle for grazing by increasing average ages and weights. The typical November-weaned calf produced by current management systems may be too heavy to be desirable to go to grass in May.

Stored feed is a strategy for reducing risk. Fifty years ago, ranchers commonly had one-half to a full year's feed needs on hand at all times. As haying systems, transportation systems, and crop yields have changed, ranchers are less reliant on feed stocks stored for emergencies, such as drought. This trend is validated with the understanding that hay harvested with modern technology can suffer dramatic loss of dry matter due to weathering during wet years. Round bales have a greater surface per ton of hay stored vs the large hay stacks of yesteryear. Improved transportation systems in South Dakota and the region facilitate the movement of harvested 


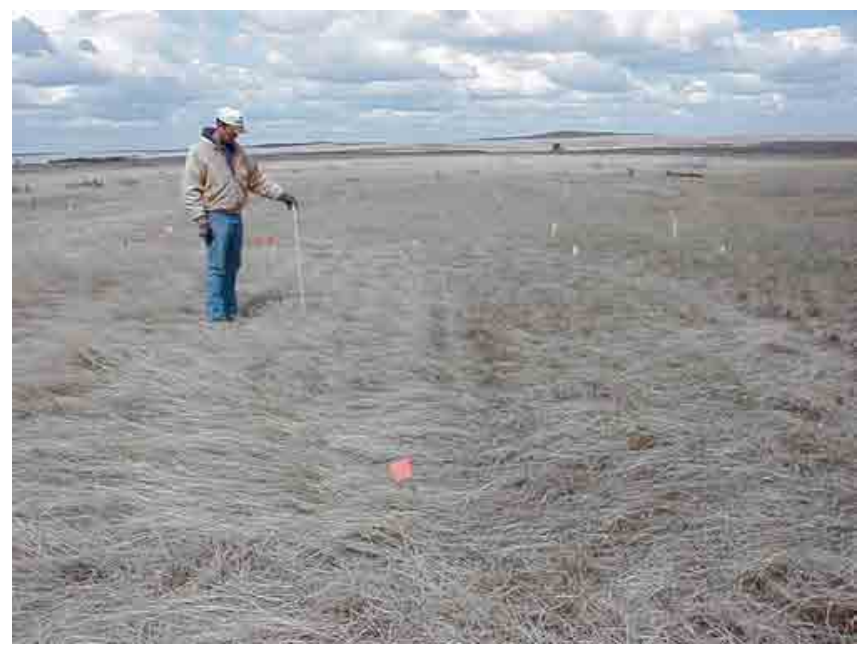

Antelope Research Station in June 2002, located approximately 15 miles east of Buffalo, SD. Note the lack of green grass in this spring drought.

feed across long distances as well as the movement of livestock to feed supplies in regions unaffected by drought.

Reluctance to destock during drought can be associated with a rancher's valid concerns for the unpredictable impact that decisions may have on a ranching operation's financial situation. Sale of a large portion of a ranch's cow inventory will increase income for the fiscal year affected by the drought. However, it can have dramatic negative impacts on income in future years and unpredictable impacts on expenses. Ranch net income can actually increase during a drought, generating a tax liability, while decreasing net income in future years that may be needed for debt service or family needs like education. Cattle sold during the drought are often discounted in the marketplace due to increased supply, decreased demand, poor livestock condition, and untimeliness. Market value of livestock may be depressed below book value or balance-sheet values, which causes problems with net-worth statements and potentially with lenders.

\section{Policy}

Federal and state policy beginning in the 1930s, but even more so over the last 40 years, has generally been to provide aid to ranchers faced with the consequences of drought. This has taken many forms, including cash subsidies, low-interest-rate loans, various types of feed, use of Conservation Reserve Program land, tax-law changes, transportation subsidies, water development, cost-share programs for resource development, information networking, and counseling services. As described in a review article of federal disaster policy including drought, Barry Barnett ${ }^{5}$ outlines how billions of dollars have been paid to farmers and ranchers in drought aid over the last 25 years. One unintended consequence to these policies is to encourage overuse of already stressed pastures and rangeland resources by encouraging livestock owners to hold livestock during drought rather than sell them. This encouragement has come in the form of cash subsidies, direct feed assistance, and transportation assistance. A second unintended consequence is that appropriate drought responses by ranch managers are delayed as policy alternatives are discussed, debated, and implemented. An example of the political climate during the drought of 2002 can be found in the November 20, 2002, article in the Sioux Falls Argus Leader by Peter Harriman ${ }^{6}$ entitled, "Senate buries drought-relief bill." The long-term result is to encourage managers to maintain relatively high stocking rates and a reluctance to plan for and respond to periodic drought. Politics can exacerbate the impacts of policy as individuals leverage assistance for political gain. For example, "Lawmakers vow drought-aid fight" and "Budget bickering blocks drought aid" were actual newspaper headlines in the Sioux Falls Argus Leader ${ }^{7,8}$ in the fall and winter of 2002 and 2003. Government response to drought was an important part of the political discussion and debate in both of South Dakota's senatorial campaigns in 2002 and 2004. This is summarized in the March 5, 2003, Argus Leader story by David Kranz" entitled, "Drought hurt his chances, Thune says" and the October 6, 2004, story by Mike Madden, "Drought aid tangled in political stalemate." ${ }^{10}$ All major farm organizations have an expectation of government drought relief as part of their political platforms. As an alternative to counter-productive assistance tied to livestock numbers, rewarding farmers and ranchers for timely implementation of comprehensive drought-response strategies would have positive benefits to ranchers, rangeland and pasture resources, and society in general.

\section{Scale}

The management response to drought is impacted by the duration, severity, extent, and seasonal pattern. Spring droughts in the northern Great Plains can last 1-4 years (see article by Smart et $\mathrm{al}^{1}$ ). Actual precipitation during the drought can range from $25 \%$ to $75 \%$ of normal. The region affected can be many counties within a state or many states within a region. The financial impact of drought can vary depending on when it occurs in relationship to the cattle inventory and price cycle and other commodity markets. The scale of drought may affect the decision to destock, which ultimately determines the impact on the health and recovery of the rangeland resources. For example, if drought is perceived to be limited in scale, the inclination to retain livestock might be great. This behavior could actually exacerbate damage to rangeland resources. However, if the drought is large in scale, a rancher's sensitivity to the lack of feed may be enough to initiate destocking, reducing pressure on rangeland resources.

\section{Conclusion}

We suggest that there were four main areas that inhibit ranchers from responding to drought. These include: learning and mental models, financial considerations, government policy, and scale. Ranchers, rangeland professionals, and policy makers' sensitivity to and understanding of weather pat- 


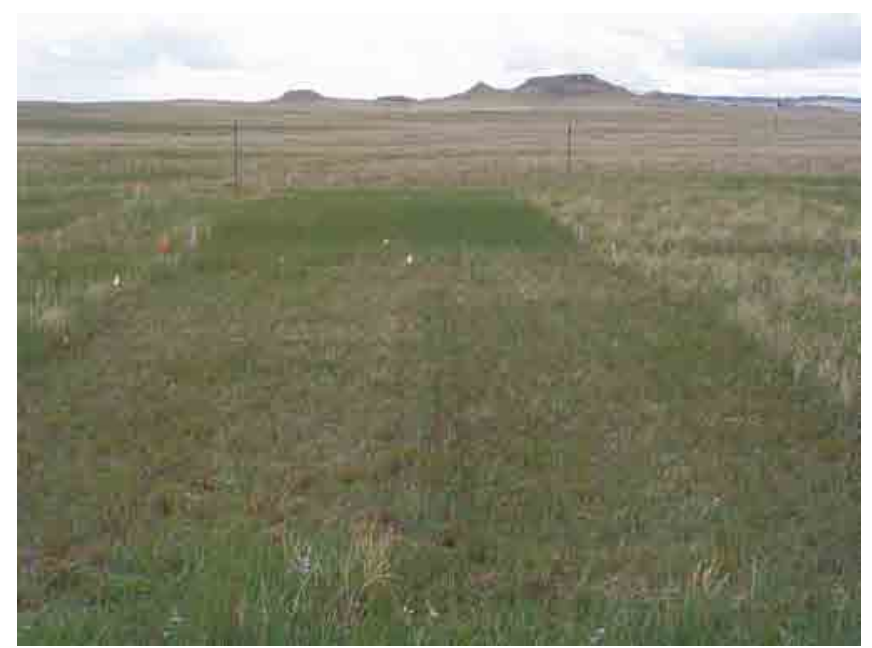

Antelope Research Station in June 2004, located approximately 15 miles east of Buffalo, SD. Note the green grass in this normal spring precipitation year.

terns, their impact on forage production, and their ability to make timely and appropriate risk assessments will help minimize and alleviate the negative financial impacts and the degradation of rangeland resources that droughts can cause. Well-thought-out and comprehensive drought-response strategies and plans are a critical part of successful ranch

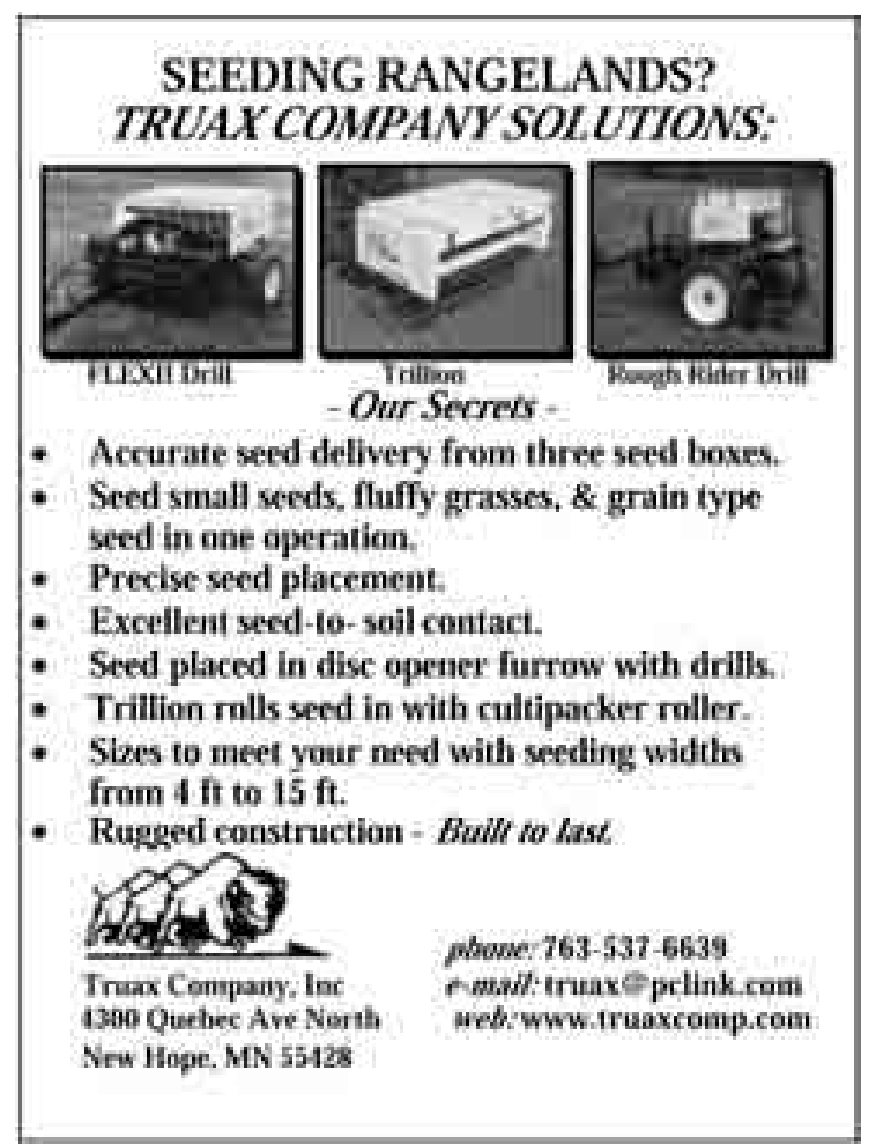

management. Government policies that reward the implementation of such comprehensive drought-management strategies and plans are also an important step for policy makers and advocacy groups to promote.

Authors are Executive Director and Endowed Chair of the King Ranch Institute for Ranch Management at Texas A $\mathcal{S}^{2} M$ University-Kingsville in Kingsville, TX (Dunn); Assistant Professor/Range Scientist in the Department of Animal and Range Sciences at South Dakota State University in Brookings, SD (Smart); Assistant Professor/Range Extension Specialist in the Department of Animal and Range Sciences at South Dakota State University in Rapid City, SD (Gates).

\section{References}

1. SMart, A. J., B. Dunn, And R. Gates. 2005. Historical weather patterns: A guide for drought planning. Rangelands 27(2):10-12.

2. SENGE, P. M. 1990. The fifth discipline: The art and practice of the learning organization. New York, NY: Doubleday. 8 p.

3. Dooley, V., C. A. Dinkel, C. A. McPeake, and E. L. LASLEY. 1982. A survey evaluation of South Dakota beef production. Journal of Animal Science 55:224-231.

4. Dunn, B. H., E. D. Hamilton, and R. J. Pruitt. 2003. Characterization of the beef cow-calf enterprise of the northern great plains. 2003 Beef Report. Brookings, SD: South Dakota State University Agriculture Experiment Station. p 54-59.

5. BARNETT, B. 2000. US government natural disaster assistance: historical analysis and a proposal for the future. Disasters 23 (2):139-155.

6. HARRIMAN, P. 20 November 2002. Senate buries drought-relief bill. Sioux Falls Argus Leader.

7. Woster, T. 25 November 2002. Lawmakers vow drought-aid fight. Sioux Falls Argus Leader.

8. Madden, M. 12 February 2003. Budget bickering blocks drought aid. Sioux Falls Argus Leader.

9. KranZ, D. 5 March 2003. Drought hurt his chances, Thune says. Sioux Falls Argus Leader.

10. MADDEN, M. 6 October 2004. Drought aid tangled in political stalemate. Sioux Falls Argus Leader.

11. USDA-NASS. 2004. Quick stats: Agricultural statistics data base. Available at: http://www.nass.usda.gov/QuickStats/. Accessed 15 December 2004. 